\title{
PLURALISME HUKUM DALAM PERBUATAN HUKUM PENGANGKATAN ANAK DI BALI
}

Oleh:

Oleh : I Gusti Agung Ayu Sukma Sanjiwani ${ }^{1}$

\begin{abstract}
Children have an important significance in the family. Adoption means taking the responsibility of other people's children from their biological parents in legal way therefore the children have the same status in the family. In Balinese Custom's law, Peperasan ceremony is an absolute requirement for adoption process. Based on Government Regulation No. 54 Year 2007 about Adoption on Article 8 Adoption customary local habits; and Adoption by the legislation. Adoption not only solved the national law but also the religious affair. Starting from these ideas, pluralism of law in the adoption of legal acts in Bali interesting to examine.
\end{abstract}

Keywords : Pluralism, Customary Law, Adoption

\section{PENDAHULUAN}

\subsection{Latar Belakang}

Anak memiliki makna dalam keluarga, sebagaimana : (1) anak merupakan pelanjut suatu generasi keluarga ; (2) anak merupakan tujuan daripada sebuah pernikahan ; (3) seorang anak sebagai ahli waris; (4) anak sebagai andalan kedua orang tua apabila orang tua sudah tidak mampu ; (5) dan dalam kepercayaan adat di Bali, anak dipercaya dapat menghantarkan arwah leluhurnya menuju surga. Atas pertimbangan tersebut, maka pantas apabila anak diberikan perlindungan oleh negara.

Menurut pendapat Soepomo pengangkatan anak adalah suatu perbuatan hukum yang melepaskan anak dari ikatan sebuah kekeluargaan dengan orang tua kandung yang memasukkan dengan cara memberikan anak tersebut ke dalam

Mahasiswa Magister Ilmu Hukum Universitas Udayana, Denpasar, Bali. Alamat JL Tukad Balian GG 43 No 2 Denpasar, e-mail: ssukmasanjiwani@ gmail.com. keluarga bapak angkatnya dan anak tersebut statusnya menjadi seperti anak kandung. Hal tersebut terdapat penjelasan bahwa anak angkat tersebut memiliki kedudukan yang sama dengan anak kandung dalam suatu hal tertentu. ${ }^{2}$ Mengangkat anak atau yang disebut adopsi adalah tindakan atau perbuatan mengambil anak baik itu dari orang lain maupun dari keluarga sehingga akan terjadi hubungan keluarga yang sama dengan anak kandung sendiri.

Dalam masyarakat hukum adat Bali hubungan kekeluargaannya adalah patrilineal sesuai dengan garis keturunan Bapak. Di dalam Hindu, anak laki-laki diharapkan dalam konteks sekala anak lakilaki Hindu menjadi ahli waris, dan dalam konteks niskala selain sebagai penerus keturunan, ia juga wajib melanjutkan pemujaan dan penyelenggaraan upacara keagamaan terutama di pura keluarga. Maka

R. Soepomo, 2000, Bab-bab Tentang Hukum Adat, Pradnya Paramita, Jakarta, hlm.103. 
seseorang yang tidak memiliki anak laki-laki seringkali dilakukan perbuatan mengangkat anak sebagai penerus keluarganya.

Berdasarkan PP No 54 Tahun 2007 mengenai Pengangkatan Anak dalam Pasal 8 Pengangkatan anak antar warga negara Indonesia sesuai meliputi :

a. Pengangkatananak disesuaikan dengan adat kebiasan setempat; dan

b. Pengangkatan anak disesuaikan dengan peraturan perundang-undangan.

Pengaturan nasional tentang pengangkatan anak diatur juga berdasarkan UU No. 35 Tahun 2014 tentang Perubahan Atas UU No. 23 Tahun 2002 tentang Perlindungan Anak dan UU No. 4 Tahun 1979 tentang Kesejahteraan Anak Pasal 12 Pengangkatan anak dilakukan untuk kepentingan kesejahteraan anak yang dilaksanakan diluar adat dan kebiasaan, dilakukan berdasarkan Peraturan Perundangundangan.

Konsep dunia nyata (sekala) dan dunia gaib disebut juga (niskala) adalah hal yang tidak dapat ditinggalkan dari kehidupan bermasyarakat di Bali yang religious. Oleh karena itu pelaksanaan pengangkatan anak tidak hanya berhubungan dengan keluarga, dalam masyarakat (banjar) melainkan juga berhubungan dengan leluhur yang bersemayam dalam sanggah atau merajan, bhuta kala, dan Ida Sang Hyang Widhi. Pengangkatan anak bukan hanya ikatan berdasarkan lahiryah semata, melainkan juga ikatan rohaniah. Pengangkatan anak tidak hanya diselesaikan secara hukum nasional melainkan juga merupakan urusan keagamaan yang melibatkan betara-betari (roh leluhur).

Dengan demikian, sahnya pengangkatan anak tersebut timbul akibat hukum yang berkaitan dengan hubunganhubungan dengan hukum kekeluargaan. Bagaimana mengenai pengangkatan anak yang dilakukan hanya berdasarkan hukum adat Bali. Dalam proses pengangkatan anak, sangatlah penting dipenuhinya persyaratanpersyaratan dalam pengangkatan anak. Bertolak dari pemikiran tersebut maka pluralisme hukum dalam perbuatan hukum pengangkatan anak di Bali menarik untuk di kaji.

\subsection{Rumusan Masalah}

Sesuai dengan paparan latar belakang tersebut, dapat ditarik rumusan permasalahan sebagai berikut:

1. Bagaimana pengaturan tentang pengangkatan anak secara substansi nasional dan adat?

2. Bagaimana konsekuensi hukum mengenai pengangkatan anak dilihat dari sudut pandang hukum adat Bali ?

\subsection{Tujuan Penelitian}

\subsubsection{Tujuan Umum}

Tujuan umum dalam penelitian adalah untuk memahami dan menganalisa tentang pluralisme hukum dalam perbuatan hukum pengangkatan anak di Bali.

\subsubsection{Tujuan Khusus}

1. Untuk membahas berkaitan hasil dari pengaturan tentang pengangkatan anak secara substansi nasional dan adat.

2. Untuk memahami dan mengetahui konsekuensi hukum terhadap pengangkatan anak dilihat dari sudut pandang hukum adat Bali. 


\section{METODE PENELITIAN}

Penelitian ini adalah penelitian hukum normatif, karena mengenai taraf perbedaan pandangan antara dua sistem hukum, yaitu hukum yang tertulis dan hukum tidak tertulis.

Pendekatan yang dilakukan terhadap penelitian yang mencakup ini adalah pendekatan konseptual dan perundangundangan. Sebagimana bahan hukum yang digunakan yaitu bahan hukum primer terdiri dari peraturan perundang-undangan dan bahan hukum sekunder terdiri dari bukubuku, literatur dan pendapat para sarjana yang sesuai dengan permasalahan yang akan diangkat.

\section{PEMBAHASAN}

3.1. Pengaturanmengenai Pengangkatan Anak Secara Substansi Nasional dan Adat

Unsur-unsur dalam Negara Hukum menurut Freidrich Julius Stahl yang diilhami oleh Immanuel Kant adalah :

1. Sesuai dan mengedepankan hak-hak asasi manusia

2. Dapat memberikan perlindungan hak asasi manusia dengan baik oleh sebab itu penyelenggara negara berdasarkan trias politica

3. Pemerintah berdasarkan UndangUndang

4. Jika pemerintahan yang berlandaskan Undang-Undang masih dirasakan melanggar hak asasi manusia maka diadili secara peradilan administrasi. ${ }^{3}$

Mengenaipengaturanyangmenyangkut mengenai prosedur pengangkatan anak

Astim Riyanto, 2006, Teori Konstitusi, Penerbit Yapemdo, Bandung, hlm.274. secara hukum di Indonesia diatur secara khusus melalui PP No 54 Tahun 2007 tentang Pengangkatan Anak Pasal 1 Anak angkat adalah anak yang haknya dialihkan dari lingkungan kekuasaan keluarga orang tua, wali yang sah, atau orang lain yang bertanggung jawab atas perawatan, pendidikan, dan membesarkan anak tersebut, ke dalam lingkungan keluarga orang tua angkatnya berdasarkan keputusan atau penetapan pengadilan. Berdasarkan Pasal 12 Ayat 1 syarat anak angkat adalah berumur 18 tahun, merupakan anak yang diterlantarkan atau terlantar, berada di dalam asuhan keluarga atau di dalam lembaga pengasuhan anak dan membutuhkan perlindungan khusus dan sebagaimana diatur dalam Pasal 13 dalam undang-undang ini orang tua harus memiliki syarat-syarat sehat secara jasmani dan rohani, berusia paling rendah 30 tahun dan paling tinggi 55 tahun, memiliki agama sama dengan calon anak angkat, Memiliki kelakuan yang baik dan tidak pernah dihukum karena melakukan tindak kejahatan, status pernikahan 5 tahun, tidak pasangan sejenis, tidak atau belum memiliki anak atau hanya mempunyai satu orang anak, mampu dalam keadaan ekonomi dan social, memiliki persetujuan anak dan izin tertulis orang tua atau wali dari anak, membuat pernyataan tertulis bahwa pengangkatan anak adalah demi kepentingan yang baik bagi anak, kesejahteraan dan perlindungan anak, adanya laporan sosial dari pekerja social setempat, telah mengasuh calon anak angkat paling singkat 6 bulan, sejak izin pengasuhan diberikan dan memperoleh izin menteri atau kepala instansi sosial.

Anak angkat adat pada prinsipnya anak angkat orang lain yang diangkat oleh suatu suatu keluarga dikarenakan dia tidak 
memiliki anak sama sekali. Jadi anak angkat secara adat ini dapat perempuan dan dapat juga laki-laki. ${ }^{4}$ Dalam desa adat di Bali pada umumnya yang diangkat sebagai anak angkat adat adalah anak laki-laki.

Menurut pendapat H.L.A Hart " the most prominent general feature of the law at all time and places is that its existence means that certain kinds of human conduct are no longer option, but in some sense obligatory". ${ }^{5}$ (sifat hukum yang harus ditaati membuat tuntutan berperilaku manusia pada situasi tertentu tidak lagi adalah pilihan melainkan menjadi suatu keharusan dan kewajiban). Dalam kaitannya dengan pengangkatan anak, terdapat 2 konstruksi hukum nasional dan hukum adat yang memiliki cara yang berbeda dalam pelaksanaannya.

Berkaitan dengan perbuatan hukum pengangkatan anak, dalam hukum adat Bali Pengangkatan anak dapat dipandang sah dengan akibat-akibat yang mendapat perlindungan hukum apabila telah dilakukan acara pengangkatan anak yang disebut pemerasan atau widiwidana. ${ }^{6}$ Acara pemerasan adalah upacara yang wajib dan dalam rangkaian perbuatan yang meliputi upacara-upacara keagamaan dengan memakai sajen-sajen yang diselenggarakan oleh seorang rohaniawan (pedanda, pemangku) dan disaksikan oleh pihak-pihak berwenang.

Menurut I Wayan Beni dan Sagung Ngurah, menyatakan : Dalam masyarakat

Soerjono Soekanto, 2012, Hukum Adat Indonesia, Rajawali Pers, Jakarta, hlm.251.

H.L.A Hart, 1998, The Concept of Law, Claredon Press, Oxford, hlm.6.

6 Wayan P. Windia dan Ketut Sudantra, 2006, Pengantar Hukum Adat Bali, Lembaga Dokumentasi dan Publikasi Fakultas Hukum Universitas Udayana, hlm.96. hukum adatBali pengangkatan anak dianggap sah apabila telah dilaksanakan berdasarkan dengan prosedur dan persyaratan yang telah sesuai dengan hukum adat Bali, seperti persetujuan dari beberpa pihak yaitu Dewa Saksi, Manusia Saksi serta adanya Siar. ${ }^{7}$ Pendapat tersebut menyebutkan sahnya pengangkatan anak menurut hukum adat Bali harus seusai persetujuan sesuai dengan yang disebutkan. Dewa saksi diwujudkan dengan upacara Peras, sedangkan Manusia Saksi pengumuman terhadap orang tua pengangkat anak tersebut yang dilakukan di banjar atau di desa dimana yang bersangkutan yang tunduk pada hukum adatnya. Upacara meperas sebagai syarat mutlak bagi sahnya pengangkatan seorang anak.

Ter Haar memberikan pendapatnya bahwa pengangkatan anak mempunyai sifat sebagai perbuatan hukum yang rangkap, bersifat magis religious, terang dan tunai. ${ }^{8}$ Dalam pendapat tersebut perbuatan hukum pengangkatan anak memiliki sifat :

1. Adanya dua perbuatan hukum yang harus dilalui, yang satu pihak melepaskan anak tersebut dari ikatan kekeluargaan orangtua kandung dan pihak lain memasukkan anak tersebut ke dalam ikatan kekeluargaan orangtua angkatnya.

2. Magisreligious diartikanpengangkatan anak disertai upacara penyerahan benda sebagai pengganti anak

3. Terang dimaksudkan agar pengangkatan anak dianggap sah, harus disaksikan prajuru desa dan

I Wayan Beni dan Sagung Ngurah, 1989, Hukum Adat Di dalam Yurisprudensi Indonesia, Surya Jaya, Denpasar, hlm.16.

8 Ni Nyoman Sukerti, 2012, Hak Mewaris Perempuan dalam Hukum Adat Sebuah Studi Kritis, Udayana University Press, Denpasar, hlm.15. 
selanjutnya diumumkan secara luas di desa pekraman.

4. Tunai dimaksudkan bahwa pengambilan anak disertai dengan penyerahan benda sebagai pengganti pengganti anak tersebut sebelum dilakukan upacara.

Dalam hukum adat Bali juga harus memenuhi persyaratan seperti yang diatas pertama dilakukan upacara keagamaan yaitu upacara pemerasan dan kemudian anak yang diperas disiarkan dan diumumkan ke banjar atau desa pekraman untuk menggantikan kedudukan orangtua angkatnya untuk dapat menjalankan hak dan kewajibannya di banjar atau desa pekraman. Magis religious disini dimaksudkan adalah upacara pemerasan. Terang dimaksudkan pada saat disiarkan ke banjar sedangkan tunai dimaksudkan dalam hal penyerahan benda kepada orangtua sebagai pengganti pengganti anak, benda tersebut biasanya asaperadeg (seperangkat pakaian) yaitu pakaian adat Bali.

Persyaratan bagi anak yang diangkat menurut hukum adat Bali, harus memenuhi beberapa syarat yaitu

a. Anak yang belum dewasa

b. Usianya lebih muda daripada yang mengangkat

c. Diutamakan anak laki-laki. Apabila yang diangkat anak perempuan dan nantinya diinginkan menjadi penerus garis keturunan secara hukum adat Bali, anak tersebut diubah status hukumnya menjadi berstatus lakilaki (purusa) dengan jalan diterapkan sebagai sentana rajeg melalui cara perkawinan ke dalam atau perkawinan kaceburin.

\subsection{Konsekuensi Hukum Mengenai Pengangkatan Anak Dilihat Dari Sudut Pandang Hukum Adat Bali}

Sistem kekeluargaan patrilineal atau kebapaan dalam masyarakat Bali disebut dengan nama kepurusa atau purusa. Prinsipprinsip dalam sistem kekeluargaan kepurusa sama dengan sistem kekeluargaan dalam Kitab Manawa Darmasastra, yang dikenal sebagai kitab hukum Hindu. ${ }^{9}$ Hal tersebut yang menyebabkan masyarakat di Bali dikatakan dan dijiwai oleh ajaran Agama Hindu.

Pengangkan anak di Bali secara umum dikenal dengan nama "Nyenta Nayang" dengan perbuatan hukum nyenta nayang, status anak menjadi berubah, perubahan ini terjadi dengan perbuatan hukum berganda (double rechtshandelling) yaitu : ${ }^{10}$

1. Perbuatan hukum yang memiliki tujuan untuk melepaskan anak yang orang lain dari ikatan keluarganya. Biasanya dilakukan dengan cara pembakaran benang, dan membayar secara adat, yaitu berupa seribu kepeng, dan satu stel pakaian.

2. Memasukkan anak didalam lingkup keluarga yang mengangkat yang di kenal dengan nama "diperas".

Tujuanpengangkatananakadalahuntuk meneruskan kelangsungan kehidupan dalam suatu keluarga. Meneruskan kelangsungan keluarga artinya melanjutkan segala hal dan kewajiban dalam hubungannya dengan masalah parahyangan, pelemahan dan pawongan. Akibat hukum terhadap sistem kekeluargaan secara patrilineal di Bali, menyebabkan kedudukan anak laki-laki

Ibid, hlm.78.

Djaren Saragih, 1996, Pengantar Hukum Adat Indonesia, Tarsito Bandung, hlm.121. 
keberadaannya sangat menonjol, termasuk jika dihubungkan dengan warisan. Keadaan tersebut pada dasarnya dikarenakan anak laki-laki di dalam masyarakat hukum adat di Bali di samping keberadaannya sebagai penerus keturunan juga memiliki kewajiban pada kegiatan adat keluaga.

Kehidupan pada desa adat, diatur dengan perangkat hukum yang dikenal dengan hukum adat. Di Bali disebut dengan awig-awig atau dresta. Bentuk awig-awig ada yang tertulis ada yang tidak tertulis. Awig-awig antara desa satu dengan yang lainnya berbeda alasannya antara lain : Desa adat diakui sebagai persekutuan hukum yang otonom artinya desa adat berhak membuat aturannya sendiri penegakkan dan menyelesaikan masalah sepanjang yang menyangkut kehidupan desanya dan pengakuan atas "desa mewacara" (masingmasing desa mempunyai tatanan adatnya sendiri). ${ }^{11}$ Dalam hal pengangkatan anak pada setiap desa adat di Bali memiliki awigawig yang berbeda-beda.

Indonesia menggunakan sistem hukum yang memiliki sifat pluralistik (pluralisme hukum), hukum yang ada dan berlaku tidak hanya dalam pengertian hukum tertulis yang diciptakan oleh negara yang disusun oleh lembaga legislatif bersama presiden. Indonesia juga mengakui hukum adat dengan sistem hukum agama. ${ }^{12}$ Konsekuensi hukum dalam hal pengangkatan anak sesuai dengan hukum adat Bali dan hukum nasional dapat berjalan bersamaan semasih tidak

Wayan P. WIndia, 2008, Bali Mewacara Gagasan Suatu Hukum Adat (Awig-Awig) dan Pemerintahan di Bali, Pusat Penelitian Hukum Universitas Udayana, hlm.29.

12 Beni Ahmad Saebani, H. Encup Supriatna, 2012, Antropologi Hukum, Pustaka Setia, Bandung, hlm.333. bertentangan dengan ketentuan undangundang. Perbedaan yang dapat dilihat dari pengangkatan anak, jika melihat di Indonesia / hukum nasional anak yang diangkat bisa anak adopsi dari orang lain maupun anak dari garis keturunan laki-laki maupun dari perempuan sedangkan pengangkatan anak sesuai dengan hukum adat Bali mengangkat anak laki-laki dan disertai upacara pemerasan yang dianggap dan status anak sudah sah menurut hukum adat Bali.

\section{Dalam Pasal 18 B ayat (2) UUD 1945} menyatakan hukum adat diakui sepanjang: (1) masih hidup; (2) berdasarkan dan sesuai dengan perkembangan masyarakat; (3) berdasarkan dengan prinsip negara kesatuan Republik Indonesia dan; diatur dalam undang-undang. Dengan demikian, ketentuan yang tercermin di dalam hukum adat harus menyesuaikan dengan hukum nasional, artinya hukum adat yang berlaku dalam perkembangannya tidak boleh bertentangan dengan hukum nasional. Apabila bertolak belakang terhadap dua hukum ini, dalam prinsip teori hukum disebut dengan pluralisme yang lemah oleh sebab hukum adat perlu dilakukan pembinaan terhadap kebiasaan yang tidak sesuai dengan perkembangan zaman dengan menghilangkan deskriminasi yang terjadi. ${ }^{13}$ Secara persyaratan pengangkatan anak sesuai dengan adat Bali tidak banyak terdapat perbedaan dengan hukum nasional, hanya saja hukum adat Bali sesuai dengan agama hindu dan keberadaannya di tuangkan tertulis dalam bentuk awig-awig dan kebiasaan.

R. Subekti, 1974, Hukum Adat Indonesia Dalam Yurisprudensi Makamah Agung, Alumni, Bandung, hlm.124. 


\section{PENUTUP}

\subsection{Simpulan}

1. Berdasarkan tinjauan terhadap pengangkatan anak secara substani nasional diatur dalam UndangUndang Nomor 35 Tahun 2014 tentang Perubahan Atas UndangUndang Nomor 23 Tahun 2002 tentang Perlindungan Anak, UndangUndang Nomor 4 Tahun 1979 tentang Kesejahteraan Anak dan Peraturan Pemerintah Nomor 54 Tahun 2007 tentang Pelaksanaan Pengangkatan Anak dan berdasarkan hukum adat Dewa Saksi upacara peras dan Manusia Saksi, serta adanya Siar.

2. Konsekuensi hukum dalam hal pengangkatan anak dilihat dari sudut pandang hukum adat Bali harus menyesuaikan diri dengan arah hukum negara atau hukum nasional, artinya dalam pengaplikasiannya hukum adat yang sudah berlaku di dalam desa adat tidak boleh bertentangan dengan Hukum Mengenai Pengangkatan Anak yang dilihat dari sudut pandang hukum adat Bali bahwa hukum adat Bali harus menyesuaikan diri dengan arah hukum di Indonesia, artinya hukum adat yang berlaku tidak bertentangan dengan hukum negara.

\subsection{Saran}

1. Setiap anak yang diangkat harus dilindungi dan diberikan kepastian hukum baik itu secara hukum nasional maupun secara adat mengenai status sebagai anak dan hak- hak yang melakat terhadap anak.

2. Kepada Parisadha Hindu Dharma dan Majelis Utama Desa Pakraman di Bali sebaiknya melakukan penyesuaian hukum adat Bali tentang kedudukan anak angkat dengan harapan agar hukum adat yang dimaksudkan disesuaikan dengan perkembangan yang ada di dalam masyarakat dan sebaiknya mengikuti prosedur pengangkatan anak secara Hukum Nasional demi mencapai kepastian Hukum.

\section{DAFTAR PUSTAKA}

\section{Buku-Buku}

H.L.A Hart, 1998, The Concept of Law, Claredon Press, Oxford, h. 6.

Penetja, Gede 2004, Aneka Catatan tentang Hukum Adat Bali, Nadha Mandiri, Denpasar

Riyanto, Astim 2006, Teori Konstitusi, Penerbit Yapemdo, Bandung.

Saebani, Beni Ahmad, H. Encup Supriatna, 2012, Antropologi Hukum, Pustaka Setia, Bandung.

Saragih, Djaren 1996, Pengantar Hukum Adat Indonesia, Tarsito Bandung.

Subekti, R, 1974, Hukum Adat Indonesia Dalam Yurisprudensi Makamah Agung, Alumni, Bandung.

Soekanto, Soerjono, 2012, Hukum Adat Indonesia, Rajawali Pers, Jakarta.

Sukerti, Ni Nyoman 2012, Hak Mewaris Perempuan dalam Hukum Adat Sebuah Studi Kritis, Udayana, University Press, Denpasar.

Wayan P. Windia, 2008, Bali Mewacara Gagasan Suatu Hukum Adat (AwigAwig) dan Pemerintahan di Bali, Pusat Penelitian Hukum Universitas Udayana.

Windia, Wayan P dan Ketut Sudantra, 2006, Pengantar Hukum Adat Bali, Lembaga 
Dokumentasi dan Publikasi Fakultas Hukum Universitas Udayana.

\section{Undang-Undang}

Undang-undang Dasar Negara Republik Indonesia Tahun 1945

Undang-Undang Nomor 4 Tahun 1979 tentang Kesejahteraan Anak.

Undang-Undang Nomor 35 Tahun 2014 tentang Perubahan Atas Undang Undang Nomor 23 Tahun 2002 tentang Perlindungan Anak PP No 54 Tahun 2007 tentang Pengangkatan Anak. 